\title{
RANCANG BANGUN DAN UJI EFISIENSI ENERGI EVAPORATOR DOUBLE EFFECT TERMODIFIKASI UNTUK EVAPORASI NIRA TEBU
}

\author{
Design and Energy Efficiency Test of Modified Double Effect Evaporator for \\ Sugarcane Juice Evaporation
}

\author{
Sumardi Hadi Sumarlan, Khoirul Anam As Syukri* , Anang Lastriyanto, Khoirotus Syadiyah \\ Ramadani, Lailatul Maghfiroh \\ Jurusan Keteknikan Pertanian - Fakultas Teknologi Pertanian - Universitas Brawijaya \\ Jl. Veteran, Malang 65145 \\ * Penulis Korespondensi, email : khoirulanams333@gmail.com
}

Disubmit: 5 Nopember 2019 Direvisi: 6 Mei 2020 Diterima: 30 Juni 2020

\begin{abstract}
ABSTRAK
Evaporasi merupakan proses penghilangan sebagian besar air pada bahan dengan cara memberikan panas pada titik didihnya menggunakan evaporator. Proses evaporasi menghasilkan uap air yang dapat dimanfaatkan untuk pembangkitan proses serupa. evaporator double effect termodifikasi merupakan alat evaporasi dengan proses penguapan berganda dan bekerja pada tekanan dibawah $1 \mathrm{~atm}$. Energi uap yang dihasilkan dari penguapan bahan di ruang proses 1 (efek 1) akan digunakan untuk pemanasan bahan di efek 2. Tujuan penelitian adalah melakukan pengujian pada aspek teknis terutama efisiensi energi dari mesin evaporator double effect termodifikasi pada bahan nira tebu. Pengukuran dan pengamatan pada proses evaporasi dilakukan terhadap data suhu bahan dan uap, tekanan vakum, volume bahan, konsumsi bahan bakar, rendemen giling sementara batang tebu, dan pengurangan volume bahan. Pencatatan suhu, tekanan, dan volume dilakukan setiap 10 menit. Hasil pengamatan suhu titik didih bahan didapatkan sebesar $63,4{ }^{\circ} \mathrm{C}$ pada tekanan rata-rata sebesar $-60 \mathrm{CmHg}$. Pengamatan konsumsi bahan bakar menunjukkan bahwa pada 5 jam 20 menit proses rata-rata sebesar 21.312 $\mathrm{kJ} / \mathrm{jam}$. Pada efek 1 rata-rata presentase pengurangan kadar air sebesar $54 \%$ sedangkan pada efek 2 sebesar 20,7\%. Didapatkan nilai efisiensi rata-rata sebesar $56,3 \%$.
\end{abstract}

Kata Kunci : Efisiensi; Evaporator Double Effect; Evaporasi; Nira Tebu

\begin{abstract}
Evaporation is a process removing most of the water in a material by giving heat till boiling point using an evaporator. The evaporation process produces water vapor that can be used for generating similar processes. Modified double effect evaporator is an evaporation tool with multiple evaporation processes and works under pressure $1 \mathrm{~atm}$. The steam energy generated from the evaporation of material in process chamber 1 (effect 1) will be used to heat the material in effect 2. The purpose of this research is to test the technical aspects, especially the energy efficiency of the modified double effect evaporator on the sugar cane juice. Measurements and observations on the evaporation process are carried out on data of material temperature and vapor, vacuum pressure, material volume, fuel consumption, temporary milled yield of sugarcane, and reduction in material volume. Recording temperature, pressure, and volume is recorded every 10 minutes. Observation of material boiling point temperature was $63.4^{\circ} \mathrm{C}$ and average pressure was $60 \mathrm{CmHg}$. The results of observations of fuel consumption showed that in about 5 hours 20 minutes the average process was 21,312 $\mathrm{kJ} /$ hour. In effect 1 the average reduction in water content was $54 \%$ while in effect 2 it was $20.7 \%$. Obtained an average efficiency value of $56.3 \%$.
\end{abstract}

Keywords: Double Effect Evaporator; Efficiency; Evaporation; Sugarcane Juice 


\section{PENDAHULUAN}

Salah satu proses operasi skala besar di dalam industri pangan adalah penguapan. Pada pengolahan pangan, seringkali suatu bahan mentah masih mengandung jumlah air yang lebih banyak daripada yang dibutuhkan pada hasil akhir. Salah satu fungsi dari penguapan adalah sebagai proses pengurangan kadar air dan berat bahan dalam bentuk cairan. Salah satu jenis alat yang digunakan untuk penguapan adalah evpaorator. Dalam evaporator, proses evaporasi terjadi dimana exhaust steam dari turbin akan masuk di sisi shell dan memanasi nira jernih yang ada di sisi tube. Kandungan air pada nira jernih akan teruapkan oleh panas dari steam. Nira jernih kemudian mengental sedangkan exhaust steam akan terkondensasi menjadi kondensat (Storia, 2016).

Salah satu item paling penting dalam proses penguapan menggunakan evaporator adalah konsumsi energi. Hal tersebut disebabkan penguapan merupakan salah satu proses konversi energi menjadi panas untuk menghasilkan uap air. Biaya operasi sistem evaporator sebagian besar ditentukan oleh energi yang diperlukan untuk mencapai tingkat penguapan tertentu (Sorour, 2015). Pada evaporator efek tunggal (single effect) hasil dari penguapan berupa steam akan terbuang menjadi kondensat. Padahal steam yang keluar dari proses evaporator efek tunggal memiliki potensi energi panas yang cukup besar jika digunakan kembali dalam proses penguapan (kalor uap air = $2.268 \mathrm{~kJ} / \mathrm{kg}$ ). Dalam kondisi steady harus ada keseimbangan antara energi yang masuk dan keluar dari sistem. Energi dapat dihemat dengan menggunakan kembali uap yang terbentuk dari produk mendidih. Salah satu dari beberapa cara untuk mencapai hal tersebut adalah dengan penguapan efek jamak (multiple effect) (Gunajit dan Surajit 2010).

Optimalisasi proses selalu menjadi tujuan utama dalam perancangan suatu mesin untuk pengembangan dan peningkatan proses di seluruh sistem makanan (Nuñezl et al., 2010). Sebagai contoh dalam sistem adalah penentuan jumlah efek optimal dalam sistem penguapan. Berdasarkan penelitian Sorour (2015) didapatkan sistem double effect (efek ganda) memiliki nilai optimum dalam segi biaya dan penggunaan energi. Hal tersebut disebabkan oleh adanya keseimbangan ekonomi antara penghematan energi dan investasi tambahan dalam pembuatan jumlah efek. Sehingga sistem double effect dipilih sebagai dasar perancangan mesin evaporator. Prinsip utama dari evaporator double effect merupakan langkah penghematan energi dimana uap hasil evaporasi badan pertama digunakan untuk penguapan badan kedua, begitupun selanjutnya (sesuai jumlah efek) (Storia, 2016).

Perancangan mesin evaporator sistem double effect juga didukung dengan adanya optimasi dalam penggunaan suhu dalam proses evaporasi. Suhu proses evaporasi dapat diatur berdasarkan tekanan dan dikondisikan vakum (dibawah $1 \mathrm{~atm}$ ). Berdasarkan penelitian Sukoyo et al. (2014) memaparkan bahwa titik didih nira dalam kondisi vakum sebesar $65-70^{\circ} \mathrm{C}$. Suhu evaporasi dapat diturunkan dan akan membuat pelepasan energi dapat ditekan. Selain itu dapat mencegah terjadinya karamelisasi dan pencoklatan karena suhu tinggi ketika evaporasi. Pada penelitian ini dikaji beberapa aspek penting yang menentukan keberhasilan proses, diantaranya melakukan pengujian pada aspek teknis terutama efisiensi energi dari mesin evaporator double effect dengan bahan nira tebu. Pengukuran dan pengamatan pada proses evaporasi dilakukan terhadap data suhu bahan dan uap, tekanan vakum, volume bahan, konsumsi bahan bakar, rendemen giling sementara batang tebu, dan pengurangan volume bahan.

\section{METODE}

Penelitian dilakukan selama 5 bulan mulai dari bulan Oktober 2019 sampai Februari 2020. Tempat penelitian dilakukan di Laboratorium Mekatronika Jurusan Keteknikan Pertanian, Fakultas Teknologi Pertanian Universitas Brawijaya.

Alat yang digunakan untuk penelitian diantaranya seperangkat mesin evaporator vakum double effect, kompor YUNDAI YANG5A high pressure, panel kontrol, stopwatch, 1 termokopel digital 2 termokopel analog, heat exchanger, manometer, mistar, penggiling tebu, saringan nira, dan box steorofoam. Sedangkan bahan yang digunakan dalam penelitian ini diantaranya nira tebu, air, gas LPG (Liquified Petrolium Gas) $12 \mathrm{~kg}$, es batu, natrium benzoat, dan kapur tohor. 


\section{Perancangan Desain Evaporator Double Effect}

Perancangan mesin dimulai dari proses perhitungan dimensi dari mesin dan beberapa pertimbangan dalam aspek misalnya kapasitas ruang proses, dimensi keseluruhan mesin, kapasitas pompa vakum, penempatan heat exchanger, dan bagian mesin lainnya. Selanjutnya dilakukan pendesainan dengan menggunakan software AutoCAD 2013 dan Inventor 2018. Mesin evaporator double effect yang dirancang mempunyai beberapa bagian utama diantaranya tabung proses efek 1 , tabung proses efek 2, panel kontrol, pompa vakum tipe water jet pump, saluran perpipaan, tiga sensor suhu, chamber atau wadah penampung air untuk sirkulasi pompa vakum, pemanas, dan rangka. Desain dari mesin evaporator double effect untuk proses evaporasi dapat dilihat pada Gambar 1.

\section{Perancangan Kontruksi Evaporator Double Effect}

Kontruksi dan struktur mesin evaporator disesuaikan dengan sifat bahan yang akan diproses. Salah satunya dengan menggunakan material dari steinless steel food grade 304 pada pembuatan ruang proses berbentuk tabung dan beberapa saluran perpipaan tempat aliran uap dan produk. Selain itu, penggunaan beberapa komponen seperti pompa vakum $1 \mathrm{HP}$, kompor high preesure, dan tabung LPG $12 \mathrm{~kg}$ disesuaikan dengan kapasitas dari mesin evaporator yang dibuat.

\section{Pengukuran dan Pengamatan}

\section{a. Suhu Bahan dan Suhu Uap Air}

Pengukuran suhu menggunakan tiga sensor suhu, yaitu 1 sensor pada bahan dan 2 pada uap evaporasi. Sehingga pengukuran dilakukan pada suhu bahan di efek 1 , suhu uap di efek 1, dan suhu uap di efek 2 . Pengukuran dan pengamatan suhu dilakukan setiap 10 menit dari awal proses evaporasi hingga akhir proses. Proses dilakukan sebanyak tiga kali ulangan setiap proses dengan proses masing-masing selama \pm 5 jam.

\section{b. Tekanan Vakum}

Tekanan vakum dihasilkan dari operasi pompa vakum yang yang terhubung pada tabung evaporator. Pengukuran dilakukan dengan pengamatan pressure-gauge pada dua titik, yaitu pada bagian atas ruang penguapan efek 1 dan efek 2. Satuan alat ukur vakum adalah $\mathrm{CmHg}$. Pengamatan dicatat setiap 10 menit sekali pada efek 1 dan efek 2.

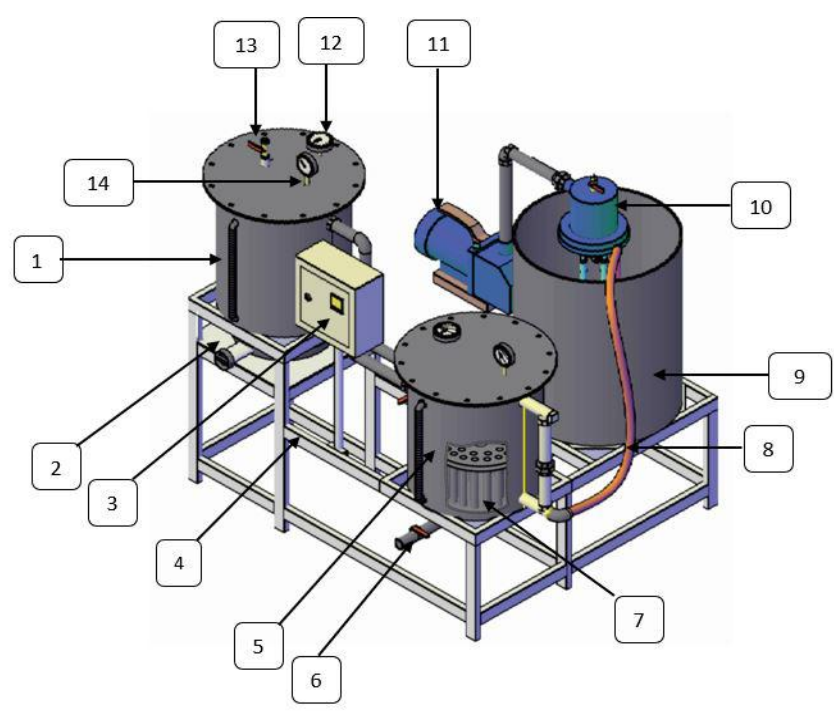

Keterangan : (1) Ruang proses efek 1, (2) Sumber panas (kompor), (3) Panel kontrol, (4) Rangka penyangga, (5) Ruang proses efek 2, (6) Valve output produk, (7) Heat Exchanger, (8) Saluran udara dari ruang proses menuju pompa, (9) Chamber/wadah air sirkulasi pompa, (10) Water jet, (11) Pompa vakum, (12) Sensor suhu (uap efek 1), (13)Valve input bahan, (14) Manometer (pengukur tekanan udara ruang tertutup)

Gambar 1. Desain dan bagian evaporator double effect 


\section{c. Volume Bahan}

Pengukuran volume bahan dilakukan sebanyak tiga kali pada setiap proses. Bahan awal masuk ke efek 1, sebanyak 50 liter. Selanjutnya pengukuran volume bahan yang keluar dari efek 1 setelah proses evaporasi tahap 1. Pengukuran terakhir pada hasil keluaran efek 2 setelah evaporasi tahap 2. Pengukuran ini dapat digunakan sebagai dasar untuk perhitungan kadar air, laju evaporasi, dan efisiensi energi.

\section{d. Konsumsi Bahan Bakar}

Konsumsi bahan bakar didefinisikan sebagai banyaknya massa gas LPG yang dikonsumsi dalam setiap proses penguapan. Pengukuran konsumsi bahan bakar dilakukan dengan cara menimbang massa awal dari gas LPG sebelum pemakaian, dan setelah pemakaian atau setelah 1 kali proses evaporasi selesai. Pengambilan data dilakukan sebanyak 3 kali ulangan. Selain itu juga dilihat pada skala regulator untuk menambah tingkat kevalidan pengukuran. Konsumsi gas LPG dapat dihitung menggunakan persamaan :

Konsumsi LPG $=\frac{\text { massa gas yang terpakai }}{\text { waktu evaporasi }}$.

Konsumsi gas LPG (kg/jam) dalam bentuk massa selanjutnya dikonversi menjadi konsumsi energi perjam. Konsumsi gas LPG menunjukkan besarnya energi input dalam proses evaporasi dalam bentuk kalor (Joule). Energi kalor dari total penggunaan bahan bakar diwakili dengan gas propana, butana, dan pentana:

$$
\mathrm{Q}_{\text {in }}=\mathrm{Q}_{\text {propana }}+\mathrm{Q}_{\text {butana }}+\mathrm{Q}_{\text {pentana } \ldots \ldots \ldots \ldots \ldots \ldots . . .}(2)
$$

Pengukuran konsumsi bahan bakar sebagai dasar dari penentuan nilai efisiensi mesin. Dimana kalor konsumsi energi merupakan $Q_{\text {in }}$ (kalor masuk) yang digunakan ketika proses. Sebelum dilakukan perhitungan pada efisiensi energi, dilakukan perhitungan untuk menentukan besarnya kalor output (Q $Q_{\text {out }}$ ). Kalor output terdiri dari dua jenis kalor, yaitu kalor sensibel (tanpa perubahan fase) dan kalor laten (dengan perubahan fase) . Berikut persamaan kalor output sebagai berikut :

$$
\mathrm{Q}_{\text {Sensibel }}=\mathrm{m} \times \mathrm{c}_{\mathrm{p}} \times \Delta \mathrm{T} \text {. }
$$$$
\mathrm{Q}_{\text {Laten }}=\mathrm{m} \times \mathrm{L}
$$

dimana $\mathrm{m}=$ massa bahan, $\mathrm{c}_{\mathrm{p}}=$ kalor jenis bahan; $\Delta \mathrm{T}=$ Perubahan suhu; dan $\mathrm{L}=$ panas laten penguapan dalam satuan $\mathrm{J} / \mathrm{kg}$.

\section{e. Efisiensi Mesin (ns)}

Keseluruhaan merupakan perbandingan antara panas yang diterima oleh bahan (untuk menaikkan suhu bahan dan mengubah fase bahan) dengan panas input dari bahan bakar yang terpakai (Qin), yang dirumuskan sebagai berikut (Supriatna, 2008):

$$
\eta \mathrm{s}=\frac{\text { Qout }}{\text { Qin }} \times 100 \% \text {. }
$$

Pada perhitungan efek 1 , $Q_{\text {in }}$ menunjukkan besarnya nilai energi kalor yang diberikan heater pada efek 1. Sedangkan Qout menunjukkan energi output dari efek 1 ( $Q_{\text {sensibel }}+$

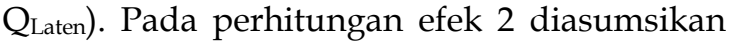
$\mathrm{Q}_{\text {in }}=\mathrm{Q}_{\text {out }}$ (mengabaikan energi hilang). Sedangkan pada $Q_{\text {out }}$ pada efek 2 menunjukkan energi output dari proses evaporasi efek 2.

\section{HASIL DAN PEMBAHASAN}

\section{Hasil Kontruksi Mesin Evaporator Double Effect}

Kontruksi mesin evaporator double effect menggunakan meterial utama steinless steel food grade tipe 304. Mesin ini terdiri dari dua tabung atau ruang proses dengan kapasitas masing-masing 50 liter dan 30 liter. Sedangkan dimensi dari mesin ini yaitu diameter $40 \mathrm{~cm}$ dan tinggi $50 \mathrm{~cm}$ (tabung evaporator). Sensor suhu ditempatkan pada tiga titik, untuk pembacaan suhu bahan, suhu uap efek 1 , dan suhu uap efek 2. Panel kontrol dilengkapi dengan display untuk menunjukkan pembacaan dari nilai suhu bahan dan setting point suhu. Sedangkan sensor suhu pada uap efek 1 dan 2 digunakan sensor analog. Kemampuan pompa vakum yang digunakan sebesar $1 \mathrm{HP}$ dengan daya 1300 watt. Saluran perpipaan terdapat tiga jalur, yaitu saluran keluaran bahan dari efek 1 ke tabung efek 2 (saluran pipa 1), saluran keluaran uap dari efek 1 menuju heat exchanger pada efek 2 (saluran pipa 2), dan saluran untuk penyedotan udara yang tehubung pada pompa vakum (saluran 3). Pada tabung efek 1 terdapat pipa input dan tabung efek 2 terdapat pipa output. Hasil kontruksi mesin dan bagian-bagiannya dijelaskan pada Gambar 2. 


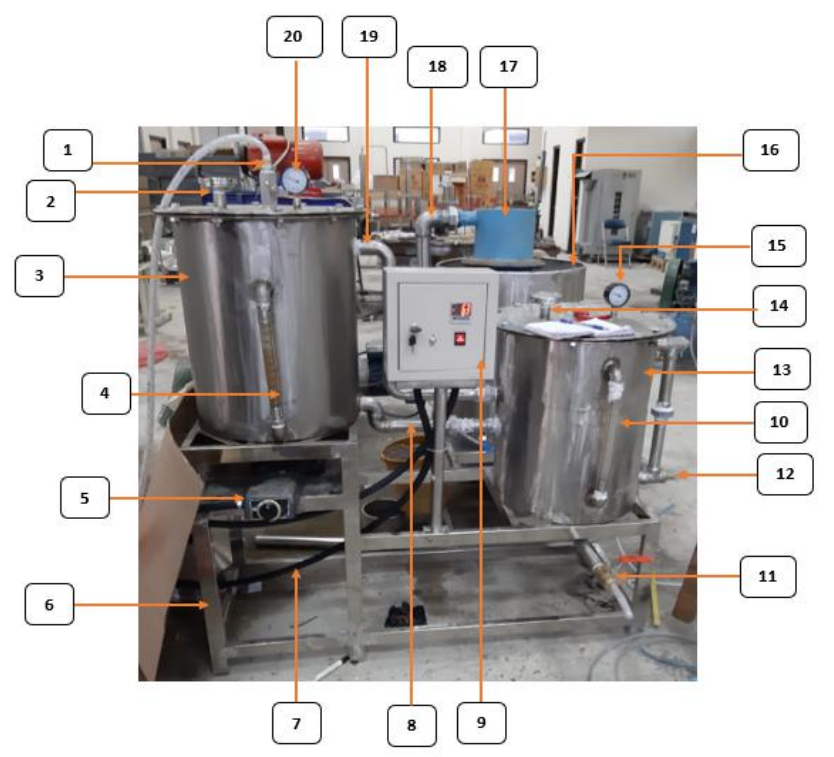

Keterangan : (1) Valve input bahan, (2) Thermometer suhu uap efek 1, (3) Chamber efek 1, (4) Indikator volume bahan 1, (5) Kompor LPG, (6) Rangka, (7) Selang LPG, Pipa saluran bahan efek 1 ke efek 2, Panel kontrol, Indikator volume bahan 1, Valve output bahan, Saluran udara dari ruang proses, menuju pompa, Chamber efek 2, Thermometer suhu uap efek 2, Chamber/wadah air sirkulasi pompa, Manometer efek 2, Water Jet, Saluran pipa jet pump, Saluran uap dari efek 1 ke efek 2, Manometer efek 1

\section{Gambar 2. Hasil kontruksi mesin evaporator double effect}

\section{Analisis Teknis}

Analisis teknis diperlukan untuk mengetahui kinerja dari mesin evaporator double effect. Kinerja tersebut akan menentukan kualitas hasil produk yang diolah, aspek energi, aspek finansial, sampai penentuan nilai efisiensi evaporator. Jika kondisi teknis masih belum sesuai dengan kondisi seharusnya, maka dapat terjadi kegagalan proses bahkan kerusakan mesin.

\section{Suhu}

Suhu menjadi faktor utama yang mempengaruhi keberhasilan proses evaporasi. Pengaturan kenaikan dan penurunan suhu serta suplai panas dalam sistem evaporasi harus dapat bekerja dengan baik sehingga tidak keluar dari batas interval suhu optimum. Sistem pengaturan tersebut harus dijaga dengan baik sehingga digunakan sistem otomatis melalui sensor termokopel yang terintegrasi dengan pemanas. Pada penelitian ini, pada sekali proses rata-rata dilakukan selama 5 jam 20 menit dilakukan sebanyak tiga kali ulangan. Dari hasil pengamatan yang telah dilakukan menggunakan mesin evaporator double effect didapatkan rata-rata titik didih aktual bahan $63,4^{\circ} \mathrm{C}$. Sedangkan suhu uap rata-rata pada efek 1 dan efek 2 masing-masing sebesar $60,4^{\circ} \mathrm{C}$ dan $57,8^{\circ} \mathrm{C}$. Suhu tersebut terjadi pada tekanan vakum, yaitu rata-rata $-60 \mathrm{cmHg}$. Grafik hasil dari hubungan suhu bahan dan uap terhadap waktu dapat dilihat pada Gambar 3.

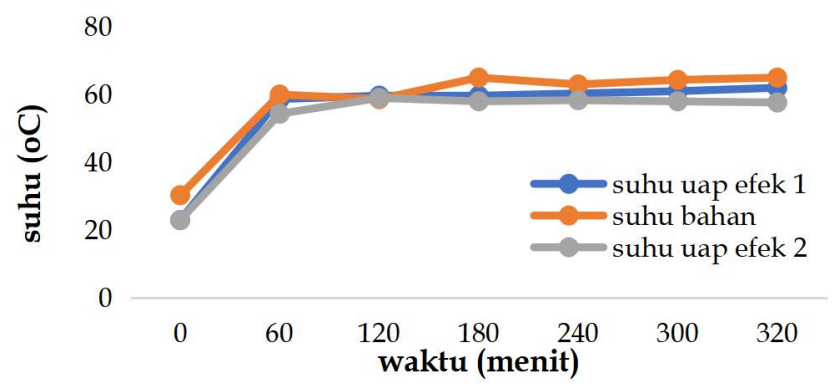

Gambar 3. Grafik hubungan suhu bahan dan uap kedua efek dengan waktu 
Berdasarkan grafik diatas diketahui bahwa suhu bahan memiliki nilai tertinggi dari suhu uap efek 1 dan uap efek 2 dengan selisih rata-rata sebesar $3-4^{\circ} \mathrm{C}$. Sedangkan suhu uap efek 1 lebih besar daripada efek 2 dengan selisih rata-rata sebesar $2-3^{\circ} \mathrm{C}$. Dari grafik tersebut juga menunjukkan bahwa titik ddih bahan dicapai dalam waktu \pm 60 menit. Pola grafik menunjukkan bahwa laju suhu bahan dan uap selama proses cenderung stabil dan konstan dalam interval antara $60-65^{\circ} \mathrm{C}$. Hasil ini sesuai dengan penggunaan suhu optimum pada proses evaporasi nira tebu, yaitu berkisar antara $60-80^{\circ} \mathrm{C}$ pada kondisi vakum (di-bawah $1 \mathrm{~atm}$ ). Seperti pada penelitian Sukoyo, et al. (2014) yang menyebutkan bahwa didapatkan nilai ${ }^{\circ}$ brix tertinggi pada suhu $60^{\circ} \mathrm{C}$ dengan $75 \%$ brix dibandingkan dengan suhu $70^{\circ} \mathrm{C}$ dan $80^{\circ} \mathrm{C}$ pada kondisi vakum. Dalam penelitian lain menyebutkan bahwa dengan suhu $70^{\circ} \mathrm{C}$ menghasilkan rendemen gula terbanyak yaitu $8,23 \%$ pada kondisi vakum (Dewi et al., 2014).

\section{Laju Pengurangan Volume dan Evaporasi}

Laju evaporasi merupakan laju penurunan kadar air dari bahan karena terjadi proses evaporasi melalui pemanasan dalam waktu tertentu. Laju evaporasi juga dapat disebut juga laju pengurangan volume air dari suatu zat yang diproses. Pada penelitian ini laju evaporasi terjadi pada dua ruang proses, yaitu pada efek 1 dan efek 2. Grafik dari laju pengurangan volume air proses evaporasi dapat dilihat pada Gambar 4 (a) dan (b).

Berdasarkan grafik diatas menunjukkan perbedaan signifikan antara laju pengurangan kadar air pada efek 1 dan efek 2 . Pada efek 1 digunakan volume awal 50 liter dan pada efek 2 voleme awal rata-rata 26 liter. Volume bahan efek 2 merupakan hasil dari proses evaporasi efek 1. Pada efek 1 rata-rata selisih pengurangan volume air sebesar 24 liter atau setara dengan presentase pengurangan $52 \%$ air dari volume awal (50 liter). Sedangkan pada efek 2 terjadi selisih pengurangan rata-rata 5,3 liter atau dengan presentase sekitar $20,7 \%$. Hasil tersebut kemungkinan dipengaruhi oleh faktor besar sumber panas, volume air bahan, dan ikatan air pada bahan.
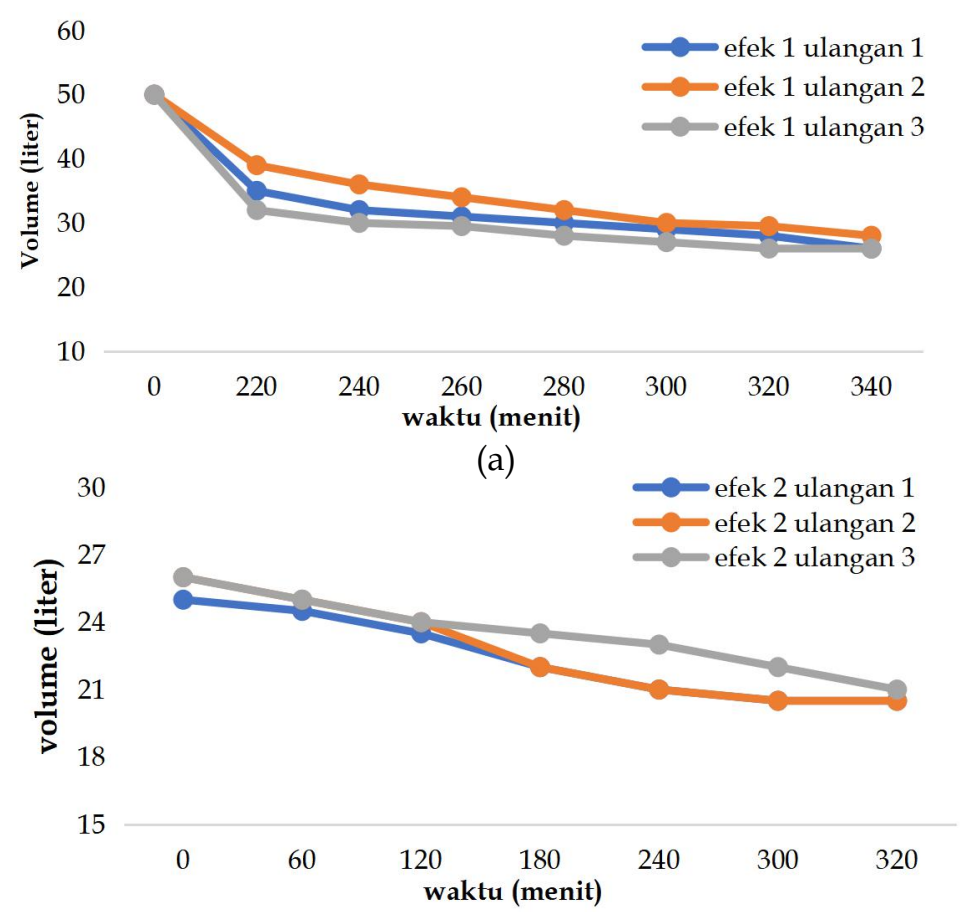

(b)

Gambar 4. Grafik laju penguapan volume air (a) efek 1 dan (b) efek 2 dengan 3 kali ulangan 
Pada efek 1 sumber panas yang digunakan adalah berasal dari pemanas kompor dengan pindah panas secara konveksi dan konduksi. Panas dari sumber panas berupa gas LPG diberikan secara langsung pada tabung efek 1 sehingga panas yang dihasilkan lebih besar. Sedangkan pada efek 2, sumber panas yang digunakan adalah energi panas yang berasal dari uap proses evaporasi efek 1 . Pada sub bab pembahasan suhu telah dijelaskan bahwa terdapat selisih suhu sekitar $3-4^{\circ} \mathrm{C}$ antara suhu dari efek 1 dengan efek 2 . Hal tersebut tentunya akan berpengaruh pada proses penguapan air pada kedua efek.

Kemungkinan berikutnya yaitu besarnya kadar air dari bahan yang diproses. Pada efek 1 bahan yang diproses memiliki kadar air yang tinggi jika dibandingkan dengan bahan yang berada pada efek 2 . Pada efek 1 bahan yang diproses adalah bahan awal dengan besar kadar air sekitar $79-80 \%$. Pada efek 2 bahan yang diproses memiliki kadar air sekitar 55-60\%. Besarnya volume pada bahan yang diproses akan mempengaruhi pelepasan air dari bahan tersebut. Sesuai dengan pola grafik laju pengurangan volume pada gambar 4. Semakin sedikit kadar air dari suatu bahan, maka pelepasan air dari bahan tersebut akan semakin berat. Seperti pernyataan dari Amanto, et al. (2015) bahwa perpindahan massa uap air terjadi karena perbedaan tekanan uap di permukaan bahan dengan ruang pengering, jika perbedaan tersebut semakin besar maka laju pengeringan akan semakin cepat. Laju penguapan adalah banyaknya massa air yang dapat dikeluarkan dari bahan per satuan waktu.

\section{Konsumsi Bahan Bakar}

Kebutuhan energi dalam hal ini adalah pada konsumsi bahan bakar. Pengukuran ini dilakukan untuk mengetahui jumlah kg LPG sebagai bahan bakar yang digunakan dalam setiap jam proses evaporasi, serta untuk mengetahui energi panas yang dihasilkan dari pembakaran yang digunakan untuk proses tersebut. Pada penelitian ini proses evaporasi nira tebu menggunakan evaporator efek ganda dilakukan tiga kali ulangan. Massa tabung awal yang digunakan adalah $25,5 \mathrm{~kg}$ dan massa akhir tabung $18 \mathrm{~kg}$, sehingga kon-sumsi gas LPG yang digunakan adalah sekitar 7,5 kg. Kalor yang dilepas LPG adalah total panas pembakaran dari gas-gas yang terdapat didalam LPG $(29,25 \%$-b propana, $68,25 \%$-b butana dan 2,5\% -b pentana). Adapun kalor pembakaran untuk tiap bahan yang terdapat didalam LPG adalah sebagai berikut:

- Kalor pembakaran propana $=12030 \mathrm{kcal} / \mathrm{kg}$

- Kalor pembakaran butana $=11830 \mathrm{kcal} / \mathrm{kg}$

- Kalor pembakaran pentana $=11600 \mathrm{kcal} / \mathrm{kg}$

Hasil perhitungan dari konsumsi bahan bakar pada tiap proses dengan tiga kali ulangan dapat dilihat pada Tabel 1 .

Pada ulangan 1 dan 2 nilai konsumsi bahan bakar tidak berbeda signifikan karena waktu proses yang dilakukan saat evaporasi lebih lama yaitu 340 dan 342 menit dibandingkan dengan ulangan ketiga selama 290 menit. Pada ulangan 1 dan 2 sekitar 12000 kJ kalor atau setara dengan 2,4 kg LPG sedangkan pada ulangan ketiga sekitar $103000 \mathrm{~kJ}$ atau setara dengan 2,1 kg. Maka dapat dihitung penggunaan bahan bakar setiap 1 jam adalah sebesar $21.312 \mathrm{~kJ}$. Sehingga semakin lama proses, semakin besar bahan bakar yang digunakan (Supriatna, 2008).

\section{Kesetimbangan massa}

Terdapat dua proses yang melibatkan perhitungan kesetimbangan massa. Yaitu proses preparasi sampel nira tebu dan proses evaporasi nira tebu. Pada proses evaporasi ulangan I bahan input nira tebu yang digunakan adalah sebanyak 50 liter. Skema neraca massa ditampilkan pada Gambar 5.

Tabel 1. Konsumsi bahan bakar

\begin{tabular}{cccc}
\hline Ulangan & Waktu (menit) & Konsumsi LPG (kg) & Nilai Kalor Total (kJ) \\
\hline $\mathbf{1}$ & 342 & 2,44 & 121481 \\
$\mathbf{2}$ & 340 & 2,43 & 120774 \\
$\mathbf{3}$ & 290 & 2,07 & 103013 \\
\hline
\end{tabular}




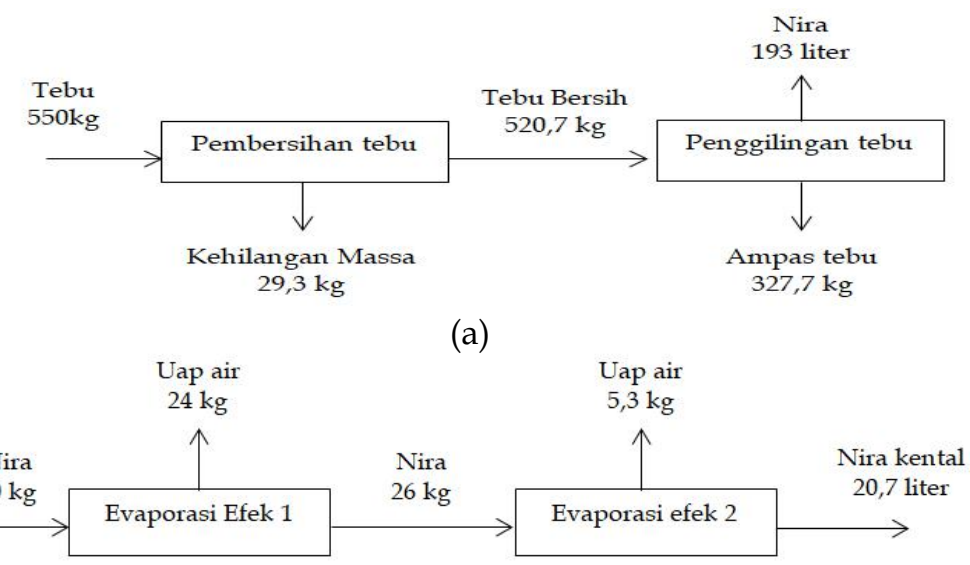

(b)

Gambar 5. Skema kesetimbangan masssa (a) preparasi sampel (b) proses evaporasi

Berat tebu awal sebesar $550 \mathrm{~kg}$ setelah panen. Selanjutnya diproses hingga menjadi nira tebu sebanyak 193 liter. Sehingga didapatkan rendemen giling sementara batang tebu sebesar 35,09\%. Rendemen giling sementara merupakan hasil nira tebu dari proses penggilingan. Banyaknya bahan yang diproses dengan evaporator efek 1 sebanyak 50 liter dan didapatkan bahan yang keluar dari efek 1 ratarata 26 liter. Bahan dipanaskan di evapo-rator efek 2 dengan menggunakan energi uap panas yang berasal dari evaporator efek I. Sehingga terjadi penguapan air bahan sebanyak $5,3 \mathrm{~kg}$ dan massa output/keluaran bahan dari efek II rata-rata sebesar 21,7 liter.

\section{Efisiensi Energi Evaporator Double Effect} Termodifikasi Keseluruhan (Overall)

Efisiensi energi mesin yang dianalisis terdiri dari 2 titik, yakni efisiensi pada ruang proses efek 1 dan efek 2. Efisiensi efek 1 merupakan perbandingan antara energi panas yang digunakan untuk menaikkan suhu bahan sampai pada titik didih ditambah energi yang digunakan untuk mengubah air menjadi uap dengan energi panas yang dihasilkan dari pemanas gas LPG. Semakin besar nilai perbandingan atau prosentasenya maka semakin efisien sistem tersebut.

Efisiensi alat keselurahan dapat diketahui dengan cara membagi total energi output yang digunakan selama proses (panas sensibel untuk menaikkan suhu sampai titik didih dan panas laten untuk menguapkan air) dengan energi input dari bahan bakar LPG yang digunakan. Adapun data efisiensi keseluruhan alat evaporator double effect termodifikasi dapat dilihat pada Tabel 2.

Tabel 2. Data hasil efisiensi keseluruhan

Efek 1 Efek 2

\begin{tabular}{ccccccc}
\cline { 2 - 6 } Ulangan & $\begin{array}{c}\mathbf{Q}_{\text {input }} \\
\mathbf{( k J )}\end{array}$ & $\begin{array}{c}\mathbf{Q}_{\text {Sensibel 1 }} \\
\mathbf{( k J )}\end{array}$ & $\begin{array}{c}\mathbf{Q}_{\text {Laten 1 }} \\
\mathbf{( k J )}\end{array}$ & $\begin{array}{c}\mathbf{Q}_{\text {Sesnsibel 2 }} \\
\mathbf{( k J )}\end{array}$ & $\begin{array}{c}\mathbf{Q}_{\text {Laten 2 }} \\
\mathbf{( k J )}\end{array}$ & $\begin{array}{c}\text { Efisiensi energi } \\
\text { kedua efek (\%) }\end{array}$ \\
\hline 1 & 121481,25 & 7641,39 & 61310,40 & & & 56,76 \\
2 & 120774,81 & 6687,53 & 51886,78 & 54,26 & 12971,14 & 59,28 \\
3 & 103013,79 & 4258,55 & 56407,45 & 64,84 & 17678,37 & 76,12 \\
4 & 47521,87 & 416,82 & 9368,36 & 66,96 & 5888,97 & 33,12 \\
\hline
\end{tabular}

Keterangan :

*efisiensi ulangan 1 = evaporasi terjadi pada efek 1 tanpa ada bahan pada efek 2

*efisiensi ulangan 2 dan 3 = evaporasi terjadi pada bahan di efek 1 maupun efek 2

*efisiensi ulangan 4 = evaporasi terjadi di efek 1 (bahan air) dan efek 2 (bahan nira tebu) 
Berdasarkan data yang telah diperoleh, rata-rata keseluruhan efisiensi dari evaporator double effect sebesar 56,32\%. Nilai efisiensi terbesar pada ulangan ke 3 dengan efisiensi sebesar $76,12 \%$. Sedangkan efisiensi terkecil pada ulangan ke 4 yaitu sebesar $33,12 \%$. Hasil tersebut telah relevan jika dibandingkan dengan beberapa penelitian lain. Misalnya penelitian dari Muhlisin et al. (2015) pada evaporator untuk proses gula merah tebu didapatkan nilai rata-rata efisiensi energi sebesar $62,5 \%$. Nilai terendah sebesar $54,62 \%$ dan nilai tertinggi sebesar $74,94 \%$.

Pada ulangan ke 4 digunakan air pada efek 1 untuk menghasilkan uap yang digunakan untuk memanaskan bahan di efek 2 . Sehingga terjadi perbedaan signifikan diantara hasil dari efisiensi mesin. Hal ini dapat terjadi karena energi input yang diberikan tidak sebanding dengan energi output atau energi panas yang digunakan selama proses penguapan. Dimana energi output lebih kecil dibandingkan dengan energi input yang diberikan. Hal tersebut menunjukkan bahwa energi kalor yang dihasilkan air lebih kecil dibandingkan dengan nira tebu ketika menjadi steam.

\section{SIMPULAN}

Mesin evaporator double effect yang dirancang menggunakan material steinless steel food grade 304 dengan kapasitas 50 liter pada efek 1 dan 30 liter pada efek 2 dan menggunakan daya pompa vakum 1300 watt. Proses evaporasi dilakukan pada 2 efek, yaitu efek 1 dan efek 2 . Bahan nira tebu yang digunakan sebanyak 50 liter. Nilai rendemen nira tebu sebesar $37,23 \%$. Pada efek 1 sebanyak rata-rata $26 \mathrm{~kg}$ uap air dapat diuapkan, dan pada efek 2 sebanyak 5,3 kg uap air. Sehingga total penguapan sebesar $31,3 \mathrm{~kg}$ uap air, dan massa akhir 21,7 liter nira tebu. Total air yang dapat diuapkan sebanyak Hasil tersebut dapat dipengaruhi oleh besar sumber panas, volume air bahan, dan ikatan air pada bahan. Konsumsi bahan bakar menggunakan LPG menunjukkan penggunaan bahan bakar perjam adalah sebesar $21.312 \mathrm{~kJ}$. Didapatkan rata-rata keseluruhan efisiensi dari evaporator double effect sebesar $56,32 \%$. Nilai efisiensi terbesar pada ulangan ke 3 dengan efisiensi sebesar $76,12 \%$. Sedangkan efisiensi terkecil pada ulangan ke 4 yaitu sebesar $33,12 \%$.
Pada penelitian ini masih ditemukan beberapa hasil yang masih dibawah standar, misalnya pada uji kadar air, dan derajat brix. Sehingga dapat dilakukan penelitian lanjutan untuk meningkatkan performa dari mesin evaporator double effect melalui perbaikan pada beberapa komponen, desain, dan sistem.

\section{DAFTAR PUSTAKA}

Amanto, B.S., Siswanti, Angga A. 2015. Uji performansi dan keseimbangan massa evaporator vakum double jacket tipe water jet dalam proses pengolahan gula merah tebu (Saccharum officinarum L.). Jurnal Teknologi Hasil Pertanian. 8(2),107-114. https://jkptb.ub.ac.id/index.php/jkptb/ article/view/253

Dewi, RS, Izza, N, Agustiningrum AD., Indriani, DW, Yusron S., Maharani DM, Yulianingsih, R. 2014. Pengaruh suhu pemasakan nira dan kecepatan pengadukan terhadap kualitas gula merah tebu. Jurnal Teknologi Pertanian. 15 (3), 149-158. https://jtp.ub.ac.id/index.php/jtp/articl e/view/446

Gunajit, S., Surajit DB. 2010. Energy Management in Multiple effect evaporator system: a heat balance analysis approach. Gen Math Notes 2010. 1, 84-88. http:/ / emis.im pa.br/EMIS/journals/GMN/yahoo_site_ admin/assets/docs/8_Energy_Managem ent_In_Multiple_Gunajit.31223741.pdf

Muhlisin, A., Yusuf H., Rini Y. 2015. Uji performansi dan keseimbangan massa evaporator vakum double jacket tipe water jet dalam proses pengolahan gula merah tebu (Saccharum officinarum L.) Jurnal Keteknikan Pertanian Tropis dan Biosistem. 3(1), 24-36. https://jkptb.ub.ac.id/index. $\mathrm{php} / \mathrm{jkptb} /$ article/view/253/207

Nuñezl, H., Simpson R., Almonacid S., Abakarov A. 2010. A study of different multi effect evaporators designed for Thermal processing of tomato paste: optimization and quality Evaluation. Journal of Biotechnology. 150, 326. https:// doi.org /10.1016/j.jbiotec.2010.09.326

Sorour, MA. 2015. Optimization of multiple effect evaporators designed for fruit juice concentrate. American Journal of Energy Engineering: Energy Conservation in Food Industry. 2(1), 6-11. https://doi.org/10.11 
10.11648/j.ajee.s.2015030201.12

Storia, EA. 2016. Pengaruh ${ }^{\circ}$ brix terhadap karakteristik perpindahan panas pada evaporator robert sistem quintuple-effect di pg. gempolkrep. Tugas Akhir. ITS. Surabaya

Sukoyo, A., Bambang DA., Rini Y. 2014. Analisis pengaruh suhu pengolahan dan derajat brix terhadap karakteristik fisiko- kimia dan sensoris gula kelapa cair dengan metode pengolahan vakum. Jurnal Bioproses Komoditas Tropis. 2(2), 170179. https://jbkt.ub.ac.id/index.php/jb $\mathrm{kt} /$ article/view/152

Supriatna, A. 2008. Uji performansi dan analisa teknik alat evaporator vakum. Tugas Akhir. IPB. Bogor 